\title{
Electrospray ionization mass spectrometric fragmentation of hydroquinone derivatives
}

\author{
Iriux Almodóvar ${ }^{1 *}$, Oney Ramírez-Rodríguez ${ }^{2}$, Andrés Barriga ${ }^{3}$, Marcos Caroli Rezende $^{1}$ \\ and Ramiro Araya-Maturana ${ }^{2}$ \\ ${ }^{1}$ Facultad de Química y Biología, Universidad de Santiago de Chile, Avenida B. O’Higgins 3363, Santiago, Chile \\ ${ }^{2}$ Facultad de Ciencias Químicas y Farmacéuticas, Departamento de Química Orgánica y Fisicoquímica, Universidad de Chile, \\ Casilla 233, Santiago 1, Chile \\ ${ }^{3}$ Unidad de Espectrometría de Masas, Facultad de Ciencias Químicas y Farmacéuticas, Universidad de Chile, Sergio \\ Livingstone Pohlhammer 1007, Independencia, Santiago de Chile
}

The fragmentation patterns of nine di-, tri- and tetracyclic hydroquinones with potential antitumor activity were rationalized by invoking competing mechanisms that included sterically accelerated homolytic cleavage, Meerweintype rearrangements and dehydrations through elimination or intramolecular nucleophilic substitution. Copyright (C) 2010 John Wiley \& Sons, Ltd.

Quinones and their reduced form, hydroquinones, are ubiquitous in nature. Several of them are obtained from natural sources ${ }^{[1,2]}$ and they display several biological activities that have been related to their redox potential. ${ }^{[3-6]}$ The quinone/hydroquinone motif has been frequently associated with anticancer activity. At present, important anticancer agents exist that show an anthraquinone, benzoquinone or naphthoquinone motif in their structures. ${ }^{[7]}$ Techniques for the characterization and structural elucidation of this type of compounds have become mandatory from the perspective of clinical and preclinical trials.

We have been interested in hydroquinones and quinones as potential antitumor and antifungal agents. ${ }^{[8-11]}$ In a previous paper we reported that 5,8-dihydroxy-4,4dimethylnaphthalen-1-one (1) and a series of derivatives inhibit tumor cell respiration. ${ }^{[8]}$ Considering that alkylation of the hydroquinone moiety should stabilize the semiquinone free radical presumably involved in the inhibition of cellular respiration, we screened another set of analogues of $\mathbf{1}$, with the general structure shown in Scheme 1, that incorporate a third and a fourth ring in the molecular structure, blocking the free positions of the aromatic ring.

A preliminary screening of these compounds showed that some of them possess higher activities as inhibitors of the mitochondrial respiration than the former compounds, and also exhibit low micromolar dose-dependent growth inhibition of the human tumor U937 cell line (human monocytic leukemia). ${ }^{[9]}$

In the course of the synthesis and characterization of these compounds, we carried out electrospray ionization mass spectrometric (ESI-MS) analysis of some of them. This versatile technique, employed in the analysis of organic compounds from biological matrices, ${ }^{[12]}$ can be associated

* Correspondence to: I. Almodóvar, Facultad de Química y Biología, Universidad de Santiago de Chile, Avenida B. O'Higgins 3363, Santiago, Chile.

E-mail: iriux.almodovar@usach.cl with the generation of protonated, ${ }^{[13,14]}$ deprotonated, ${ }^{[15]}$ metal-complexed, ${ }^{[16]}$ and radical species ${ }^{[17]}$ in the gas phase. These species can be further analyzed by tandem mass spectrometry (MS/MS). ${ }^{[18,19]}$ There are a few sources available for the structural elucidation of most classes of compounds based on dissociation of their protonated or deprotonated ions. Only small libraries of product ion mass spectra of $[\mathrm{M}+\mathrm{H}]^{+}$ and $[\mathrm{M}-\mathrm{H}]^{-}$ions have been reported for some 400 drugs. ${ }^{[20]}$ Therefore, the MS/MS study of several different classes of substances is necessary to furnish information about their fragmentation pathways. In this communication we describe the ESI spectra and sequential product ion fragmentation of nine derivatives of 5,8-dihydroxy-4,4-dialkylnaphthalen1(4H)-one (1) (Scheme 2).

The analysis of the fragmentation pathways of these compounds revealed subtle factors that led to interesting differences in their spectra. These differences include steric factors and regiospecific reaction pathways.

\section{EXPERIMENTAL}

Bicyclic hydroquinones $\mathbf{1}$ and $\mathbf{3}$ and tricyclic hydroquinones $\mathbf{2}$ and 5 were synthesized following the procedure reported by Castro et al. ${ }^{\text {[21] }}$ Synthesis of compounds 4, 6, 7, 8, 9 has not been published yet. All compounds were obtained as solids and the structures were confirmed by ${ }^{1} \mathrm{H},{ }^{13} \mathrm{C}-\mathrm{NMR}$ spectra and 2D NMR experiments (COSY, HMQC or HSQC and HMBC).

The stock solutions for ESI-MS experiments were prepared in acetonitrile and working solutions were prepared from them as follows: $20 \mu \mathrm{L}$ of stock solution, $130 \mu \mathrm{L}$ of acetonitrile and $50 \mu \mathrm{L}$ of water. Spectra were acquired in an Esquire 4000 ESI ion trap mass spectrometer (Bruker Daltonik $\mathrm{GmbH}$, Germany). Working solutions were analyzed by direct infusion $(200 \mu \mathrm{L})$ at a flow rate of $2.5 \mu \mathrm{L} / \mathrm{min}$ using a syringe pump (Cole-Parmer, IL, USA). Nitrogen was used as nebulizer gas at $10 \mathrm{psi}, 300^{\circ} \mathrm{C}$ and at a flow rate of $5 \mathrm{~L} / \mathrm{min}$. The mass spectrometric conditions for positive and negative 
<smiles>[R]C1([R])C=CC(=O)c2c(O)c3c(c(O)c21)CCCC3</smiles>

Scheme 1. General structure of studied 5,8-dihydroxy-4,4dialkylnaphthalen-1-ones.

polarity were as follows: electrospray needle, $4000 \mathrm{~V}$; end plate offset, $-500 \mathrm{~V}$; skimmer $1,30.0 \mathrm{~V}$; skimmer 2, 6.0 V; capillary exit offset, $60.0 \mathrm{~V}$; capillary exit, $90.0 \mathrm{~V}$; octopole delta, $2.40 \mathrm{~V}$; trap drive, 55.0; lens I voltage, $5.0 \mathrm{~V}$; lens II voltage, $60.0 \mathrm{~V}$. The mass spectrometer was run in full scan mode. Negative and positive ions were detected using the standard scan at normal resolution (scan speed 10,300 $\mathrm{m} / \mathrm{z} / \mathrm{s}$; peak with $0.6 \mathrm{FWHM}$ / $\mathrm{m} / \mathrm{z}$ ). The trap parameters were set in ion charge control (ICC) using the manufacturer's default parameters, and maximum accumulation time of $200 \mathrm{~ms}$. Collision-induced dissociation (CID) was performed by collisions with helium background gas present in the trap. Fragmentation was set with SmartFrag between 30 and $200 \%$; isolation width, $4.0 \mathrm{~m} / \mathrm{z}$; fragmentation amplitude, $1.0 \mathrm{~V}$; fragmentation time, $40 \mathrm{~ms}$; fragmentation delay, $0 \mathrm{~ms}$ and an average of 5 spectra.

\section{RESULTS AND DISCUSSION}

All the investigated compounds showed the corresponding $[\mathrm{M}+\mathrm{H}]^{+}$ion as the intact ionized molecule $\left(\mathrm{MS}^{1}\right)$. As expected, the second stage of fragmentation $\left(\mathrm{MS}^{2}\right)$, promoted by CID, depended strongly on the substitution pattern of the aromatic ring. Surprisingly, it also depended significantly on the nature of the alkyl group at the 4-position of the quinone ring. Table 1 lists the molecular and main fragment ions observed in the ESI-MS ${ }^{\mathrm{n}}$ analysis of hydroquinones 1-9.

Starting from the analogous structures 1, 2 and 3, we identified some common features in their spectra: loss of water, ${ }^{[22]}$ loss of one alkyl group and CO. Nevertheless, the formation of these fragments did not follow the same pathway. In one case, the $\mathrm{MS}^{2}$ spectrum of molecule 1 showed a prominent ion $[\mathrm{M}-15]^{+}$at $m / z$ 190, which was formed by the loss of a methyl radical. We also observed two<smiles>CC1(C)C=CC(=O)c2c(O)ccc(O)c21</smiles>

1<smiles>CCC1(CC)C=CC(=O)c2c(O)c3c(c(O)c21)C(C)C=CC3CO</smiles>

4<smiles>CCC1(CC)C=CC(=O)c2c(O)c3c(c(O)c21)C(CO)C=C1CCCCC13</smiles>

7<smiles>CC1(C)C=CC(=O)c2c(O)c3c(c(O)c21)CC=CC3</smiles>

2<smiles>CC1C=CC(CO)c2c(O)c3c(c(O)c21)C(C)(C)C=CC3=O</smiles>

5<smiles>CC(=O)OCC1C=C2CCCCC2c2c(O)c3c(c(O)c21)C(C)(C)C=CC3=O</smiles>

8<smiles>CCC1(CC)C=CC(=O)c2c(O)ccc(O)c21</smiles>

3
6<smiles>CC1(C)C=CC(=O)c2c(O)c3c(c(O)c21)C(CO)C=C1CCCCC13</smiles>

Scheme 2. Structures of studied hydroquinones 1-9. 
Table 1. Molecular and main fragment ions observed by ESI-MS ${ }^{\mathrm{n}}$ analysis of 1-9

\begin{tabular}{|c|c|c|c|}
\hline Cpd & $\begin{array}{c}{[\mathrm{M}+\mathrm{H}]^{+}} \\
m / z(\%)\end{array}$ & $\begin{array}{l}\mathrm{MS}^{2} \\
m / z(\%)\end{array}$ & $\begin{array}{l}\mathrm{MS}^{3} \\
m / z(\%)\end{array}$ \\
\hline 1 & 205 (100) (I) & $\begin{array}{l}\frac{190}{187}(100)(\mathrm{II})[\mathrm{II})\left[\mathrm{I}-\mathrm{CH}_{3}\right] \\
177(22)\left[\mathrm{I}-\mathrm{C} \mathrm{H}_{2} \mathrm{O}\right] \\
\end{array}$ & $\begin{array}{l}172(100) \\
144(90) \\
135(67) \\
160(61)\end{array}$ \\
\hline 2 & $257(60)(\mathbf{I})$ & $\begin{array}{l}\frac{242}{239}(100)(\mathrm{III})\left[\mathrm{I}-\mathrm{CH}_{3}\right] \\
229(14)\left[\mathrm{I}-\mathrm{H}_{2} \mathrm{O}\right] \\
\mathrm{II}-\mathrm{CO}]\end{array}$ & $\begin{array}{l}227(100) \\
224(50)\end{array}$ \\
\hline 3 & 233 (100) (I) & $\begin{array}{l}204(100)\left[\mathbf{I}-\mathrm{C}_{2} \mathrm{H}_{5}\right] \\
\underline{215}(11)(\mathrm{II})\left[\mathrm{I}-\mathrm{H}_{2} \mathrm{O}\right]\end{array}$ & $\begin{array}{l}197(35) \\
187(100)[\text { II-CO] } \\
159(59)\end{array}$ \\
\hline 4 & 329 (100) (I) & $\begin{array}{l}\frac{311}{293}(100)(\mathrm{II})\left[\mathrm{I}-\mathrm{H}_{2} \mathrm{O}\right] \\
282(33)\end{array}$ & $\begin{array}{l}293(22)\left[\mathrm{II}-\mathrm{H}_{2} \mathrm{O}\right] \\
\left.282(100) \overline{[\mathrm{II}}-\mathrm{C}_{2} \mathrm{H}_{5}\right] \\
161(17)\end{array}$ \\
\hline 5 & $301(44)(\mathbf{I})$ & $\begin{array}{l}\frac{283}{265}(100)(\mathrm{II})\left[\mathrm{I}-\mathrm{H}_{2} \mathrm{O}\right] \\
161(42)\end{array}$ & $\begin{array}{l}268(39)\left[\mathrm{III}-\mathrm{CH}_{3}\right] \\
265(100)\left[\underline{[\mathrm{II}}-\mathrm{H}_{2} \mathrm{O}\right] \\
161(62)\end{array}$ \\
\hline 6 & 341 (100) (I) & $\begin{array}{l}\frac{323}{305}(59)(\mathrm{II})\left[\mathbf{I}-\mathrm{H}_{2} \mathrm{O}\right] \\
255(100)\end{array}$ & $\begin{array}{l}305(41)\left[\text { III-H } \mathrm{H}_{2} \mathrm{O}\right] \\
255(100)\left[\underline{[\mathrm{II}}-\mathrm{C}_{4} \mathrm{H}_{4} \mathrm{O}\right]\end{array}$ \\
\hline 7 & 369 (5) (I) & $\begin{array}{l}\frac{340}{322}(28) \\
309(28)\end{array}$ & $\begin{array}{l}322(60)\left[\mathrm{II}-\mathrm{H}_{2} \mathrm{O}\right] \\
\left.309(100) \overline{[\mathrm{II}}-\mathrm{CH}_{2} \mathrm{OH}\right] \\
291(17) \\
253(17)\end{array}$ \\
\hline 8 & 383 (100) (I) & $\begin{array}{l}\frac{323(100)(\mathrm{II})\left[\mathrm{I}-\mathrm{C}_{2} \mathrm{H}_{4} \mathrm{O}_{2}\right]}{305(80)} \\
255(70)\end{array}$ & $\begin{array}{l}305(100)\left[\left[\mathrm{II}-\mathrm{H}_{2} \mathrm{O}\right]\right. \\
255(30)\left[\underline{\mathrm{I}}-\mathrm{C}_{4} \mathrm{H}_{4} \mathrm{O}\right] \\
177(22)\end{array}$ \\
\hline 9 & $341(0.5)(\mathbf{I})$ & $\begin{array}{l}\frac{323}{305}(78)(\text { II })\left[\mathrm{I}-\mathrm{H}_{2} \mathrm{O}\right] \\
254(100)\left[\mathrm{I}-\mathrm{C}_{4} \mathrm{H}_{5} \mathrm{O}-\mathrm{H}_{2} \mathrm{O}\right] \\
255(100),\end{array}$ & $\begin{array}{l}305(94)\left[\underline{\mathrm{II}}-\mathrm{H}_{2} \mathrm{O}\right] \\
255(100)\left[\underline{[\mathrm{II}}-\mathrm{C}_{4} \mathrm{H}_{4} \mathrm{O}\right] \\
295(67)\end{array}$ \\
\hline
\end{tabular}

minor ions, $[\mathrm{M}-28]^{+}$at $m / z 177$ and $[\mathrm{M}-18]^{+}$at $m / z 187$, due to elimination of $\mathrm{CO}$ and $\mathrm{H}_{2} \mathrm{O}$, respectively (Scheme 3).

Compound $\mathbf{2}$ has a third non-substituted cycle fused to the aromatic ring of hydroquinone 1 . Its fragmentation pathway is similar to molecule 1: a prominent ion $[\mathrm{M}-15]^{+}$at $m / z 242$, formed by the loss of one methyl radical, and two minor ions, [M-28] $^{+}$at $m / z 229$ and $[\mathrm{M}-18]^{+}$at $m / z$ 239, due to elimination of $\mathrm{CO}$ and $\mathrm{H}_{2} \mathrm{O}$, respectively (Scheme 4).

In the case of the ethyl analog 3 , the $[\mathrm{M}+\mathrm{H}]^{+}$ion at $m / z 233$ loses one alkyl radical (ethyl in this case) and water, affording fragments $[\mathrm{M}-29]^{+}$at $m / z 204$ and $[\mathrm{M}-18]^{+}$at $m / z 215$, respectively. However, the fragment at $m / z 187$, corresponding to the loss of $\mathrm{CO}$, is observed in the third stage of fragmentation $\left(\mathrm{MS}^{3}\right)$ from the precursor ion at $\mathrm{m} / \mathrm{z} 215$ (Scheme 5). In this compound, the loss of CO is less favored than the loss of water and alkyl group, owing to steric crowding between ethyl groups and the hydroxyl substituent of C-5, the elimination of one of them causes a greater steric relief.

Hydroquinones 4, 5 and 6 constitute another group of related compounds which showed interesting features and subtle differences in their fragmentation patterns. Hydroquinone 4 lost water through an intramolecular nucleophilic substitution of the neighbouring hydroxyl group at C-9 to produce ion 4-A. The $\mathrm{MS}^{3}$ spectrum of this precursor pointed to the elimination of one ethyl radical, and to loss of water, to produce 4-B and 4-C, respectively, in common with the fragmentations driven by steric crowding of the diethyl derivative 3 (Scheme 6).

Compound 5 showed the same pathway, with initial formation of ion 5-A, by dehydration of the hydroquinone through an intramolecular nucleophilic substitution, followed by elimination of one methyl radical and water, to produce ions 5-B and 5-C, respectively (Scheme 7).

Hydroquinone 6 apparently followed the same pathway, with initial loss of water to give an ion at $m / z 323$. A second dehydrated ion at $\mathrm{m} / \mathrm{z} 305$ was also observed in the $\mathrm{MS}^{3}$ spectrum. However, instead of the expected $[\mathrm{M}-15]^{+}$ion, originating from the elimination of one methyl radical, an intriguing $[\mathrm{M}-68]^{+}$fragment at $m / z 255$ was observed in the same spectrum (Scheme 8). The structure 6-B was finally assigned to this ion, and its formation rationalized in terms of the mechanism shown below, involving an intramolecular Meerwein rearrangement as its key step, followed by the elimination of the ketene $\mathrm{CH}_{2}=\mathrm{CH}-\mathrm{CH}=\mathrm{C}=\mathrm{O}, \mathrm{C}_{4} \mathrm{H}_{4} \mathrm{O}$ (Scheme 9).

For this rearrangement to take place, it was necessary to postulate a free hydroxyl group at C-7, suggesting that the first dehydration process to produce 6-A could not involve an intramolecular nucleophilic substitution by this group, as happened in compounds 4 and 5. Instead, elimination of water from the hydroxymethyl substituent of C-6 had to take place, without the intervention of the phenolic $\mathrm{OH}$ of $\mathrm{C}-7$. This process also may have occurred with hydroquinones 4 


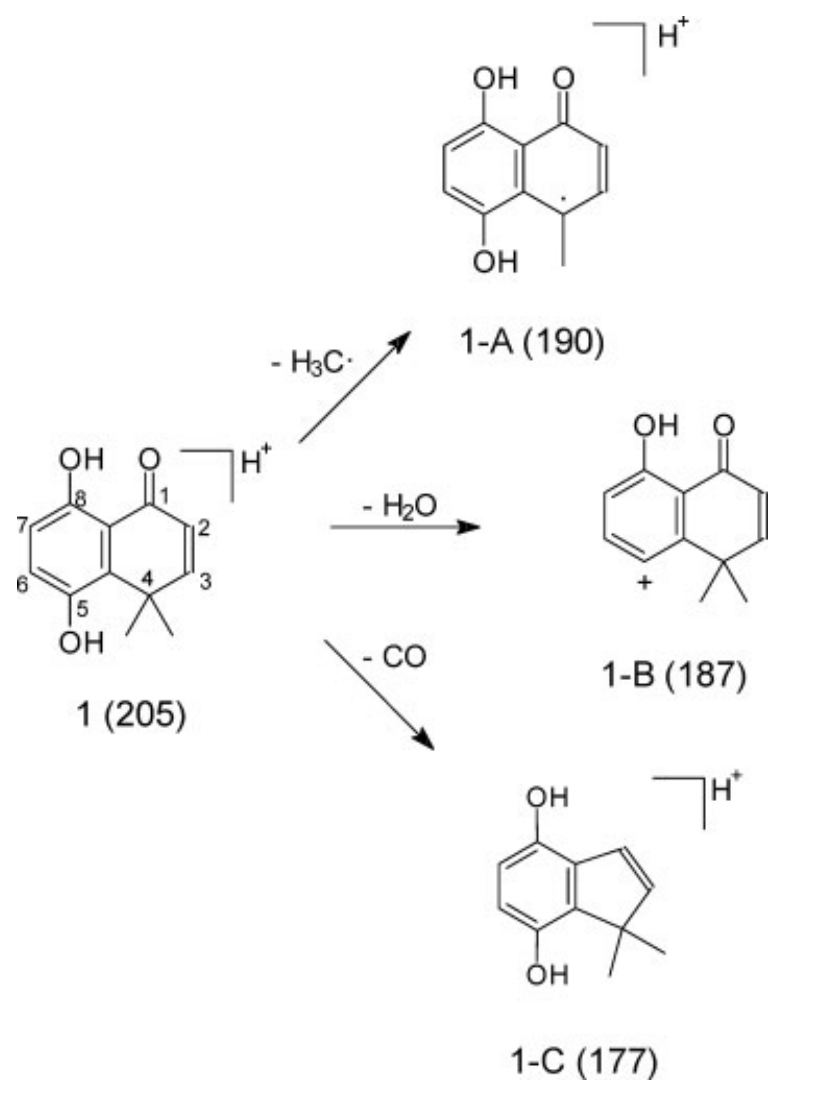

Scheme 3. Fragmentation pattern of protonated hydroquinone 1.

and 5. Therefore, there are two competing dehydrations, one of them takes place through an intramolecular nucleophilic substitution (compounds 4 and 5), and the second occurs by an elimination mechanism (compound 6).

These dehydrations may be explained through the relative stability of tertiary cations generated after the hydroxyl protonation of hydroquinones $\mathbf{5}$ and $\mathbf{6}$. These cations should be formed from a Meerwein rearrangement involving a hydride transfer from C-6. In compound 6 this process is favoured because a tertiary carbocation with two resonance<smiles>C[CH-]CC1=CC(C)c2c(O)c3c(c(O)c2C1=O)CC=CC3</smiles>

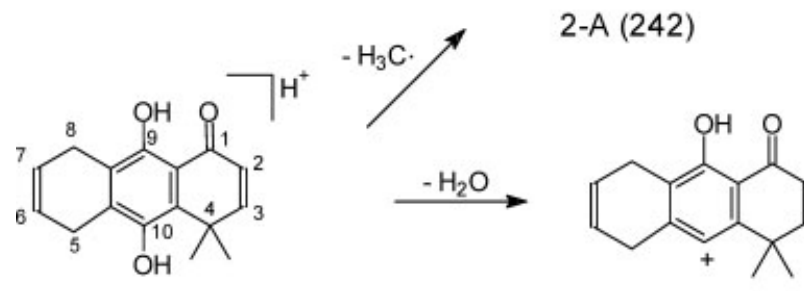

2 (257)

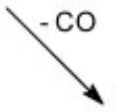

2-B (239)<smiles>CCCCCCCC</smiles>

2-C (229)

Scheme 4. Fragmentation pattern of protonated hydroquinone 2.

structures is formed. This possibility is absent in the case of compounds 4 or 5 (Scheme 10).

The fragmentation pattern of hydroquinone 7 could be rationalized with the mechanisms depicted for diethyl derivatives 3 and 4 and for tetracyclic hydroquinone 6 . Thus, the radical cation 7-A was formed by elimination of one ethyl group and the ion 7-B, observed in the $\mathrm{MS}^{3}$ spectrum, by water elimination and Meerwein rearrangement of its precursor. A second ion derived from 7-A was detected at $\mathrm{m} / \mathrm{z} 309$ and its structure was assigned (7-C, Scheme 11). Ion 7-C was formed by elimination of hydroxymethyl radical followed by a rearrangement to more stable fused aromatic fragment (Scheme 12).<smiles></smiles>

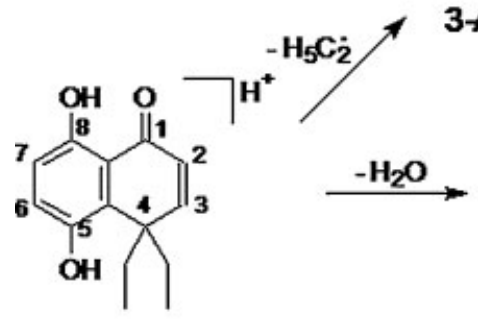

3 (233)<smiles>CCC1(CC)C=CC(=O)c2c(O)cccc21</smiles>

3-B (215)

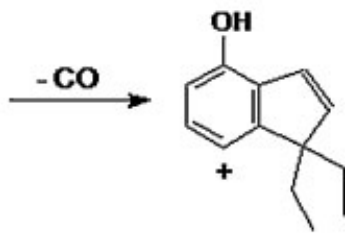

3-C (187)

Scheme 5. Fragmentation pattern of protonated hydroquinone 3. 
<smiles>CCC1(CC)C=CC(=O)c2c(O)c3c(c(O)c21)C(C)C=CC3CO</smiles>

$4(329)$

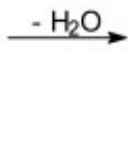

$4-A(311)$

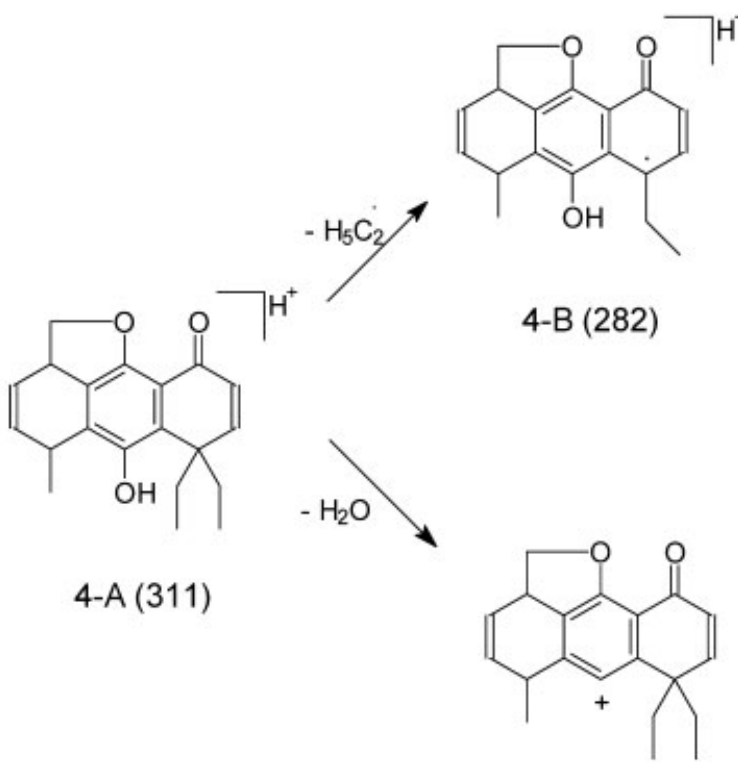

4-C (293)

Scheme 6. Fragmentation pattern of protonated hydroquinone 4.

The hydroquinone 8 shows a fragmentation pattern in agreement with what should be expected from the preceding analysis of the spectrum of hydroquinone 6. Elimination of one acetic acid molecule through a McLafferty rearrangement led to the ion 8-A. This ion forms 8-B by water loss. The other main fragment in the $\mathrm{MS}^{3}$ spectrum was ion $8-\mathrm{C}$, formed by the same mechanism described above for hydroquinone 6 , involving a Meerwein rearrangement followed by elimination of 1,3-butadiene-1-one (Scheme 13).
The fragmentation of hydroquinone 9 followed closely the pattern observed for 8 . Water elimination from the hydroxymethyl substituent at C-6 replaced the McLafferty rearrangement observed for 8 , leading however to the same precursor 8-A. As expected, this ion generated, in the $\mathrm{MS}^{3}$ spectrum, ions 8-B and 8-C. A surprising observation, however, was a prominent ion at $m / z 254$ in the $\mathrm{MS}^{2}$ spectrum, suggesting the simultaneous elimination of one molecule of water and the fragment $\mathrm{C}_{4} \mathrm{H}_{5} \mathrm{O}$ from the<smiles>C[C+](C)C1CCC(C)(C)c2c(O)c3c(c(O)c21)[C@@H](C)C=C[C@H]3CO</smiles>

$5(301)$<smiles>[C+]OCC</smiles><smiles>CCCCC(=O)c1c2c3c(c(O)c1C(C)(C)C=CC2=O)C(C)C=CC3C</smiles>

$5-A(283)$<smiles>C[I+]I1CC=CC(C)C2C(=O)c3c(O)c4c5c(c3C(O)=C21)OCC4C=CC5C</smiles>

$5-B(268)$

Scheme 7. Fragmentation pattern of protonated hydroquinone $\mathbf{5}$. 


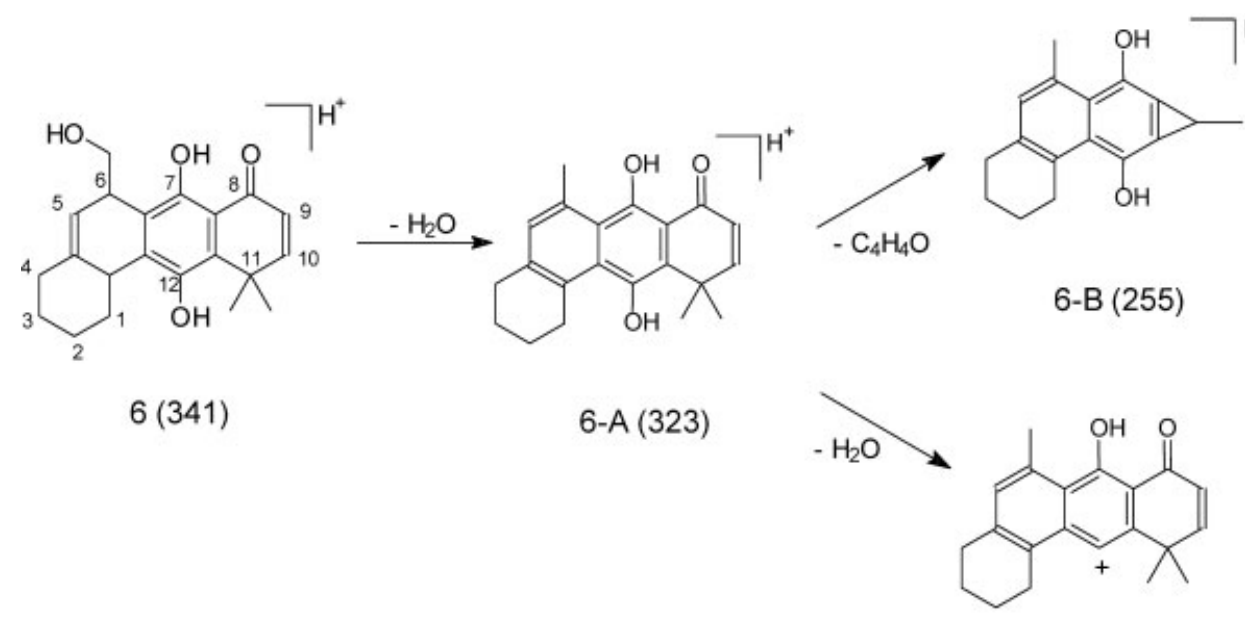

6-C (305)

Scheme 8. Fragmentation pattern of protonated hydroquinone 6.

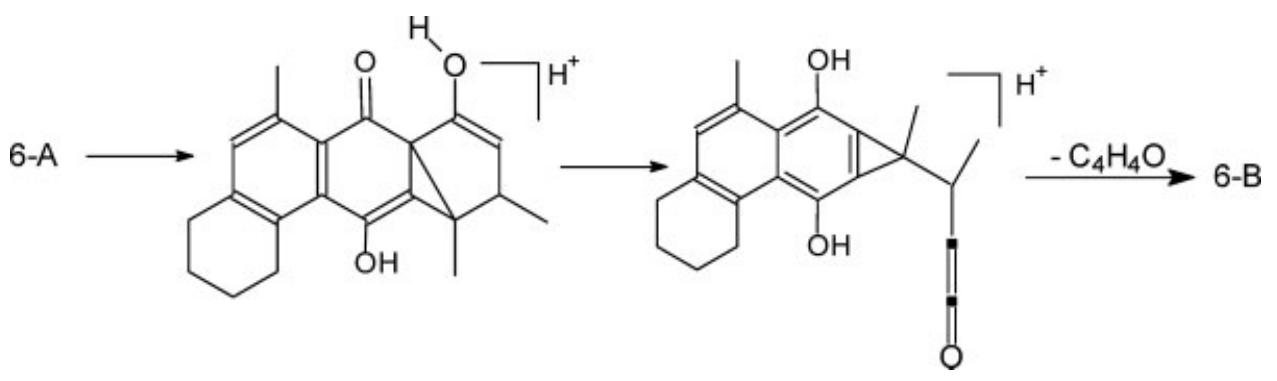

Scheme 9. Proposed mechanism of formation of 6-B from 6-A through a Meerwein-type rearrangement and loss of 1,3-butadien-1-one.<smiles>[CH2+]OC[C@@H]1C=C2CCCCC2c2c(O)c3c(c(O)c21)C(=O)C=CC3(C)C</smiles>

6<smiles>CC1C=C2CCCCC2c2c(O)c3c(c(O)c21)C(=O)C=CC3(C)C</smiles>

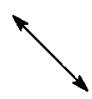

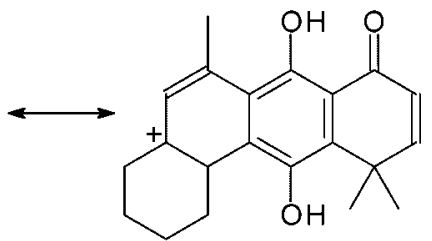

\section{6-A}

Scheme 10. Dehydration of protonated hydroquinone 6 to form 6-A.

protonated hydroquinone. This puzzling observation suggested two modes of fragmentation for the cyclohexadienone ring of $\mathbf{9}$, both involving the final loss of a ketene derivative. Following this assumption, structure 9-A was assigned to this ion (Scheme 14).

The difference in behaviour between hydroquinone 9 and its acylated derivative 8 was interpreted as arising from different degrees of steric compression of the intermediate shown in Scheme 15, in equilibrium with the protonated hydroquinone. In the case of hydroquinone $8(X=\mathrm{OAc})$, the
McLafferty fragmentation of the substituent at C-6 relieves the steric crowding around the phenolic hydroxyl. In consequence, ion 8-A is formed, and then it eliminates one molecule of 1,3-butadiene-1-one, as described in Scheme 15. In the case of hydroquinone $\mathbf{9}(\mathrm{X}=\mathrm{OH})$, the dehydration of a primary alcohol is a more sluggish process: an equilibrium is established with the rearranged isomer formed by migration of one methyl group from C-8, and the steric crowding of this molecule is relieved by homolysis of the bond between C-8 and C-9. Dehydration of this species then takes place together 
<smiles>CC[C+](C)C</smiles>

7 (369)<smiles></smiles>

7-B (322)

7-A (340)

$\downarrow-\mathrm{HOCH}_{2}$<smiles>CCc1ccc(O)c2c(O)c3c4c(ccc3c(O)c12)CCCC4</smiles>

7-C (309)

Scheme 11. Fragmentation pattern of protonated hydroquinone 7.

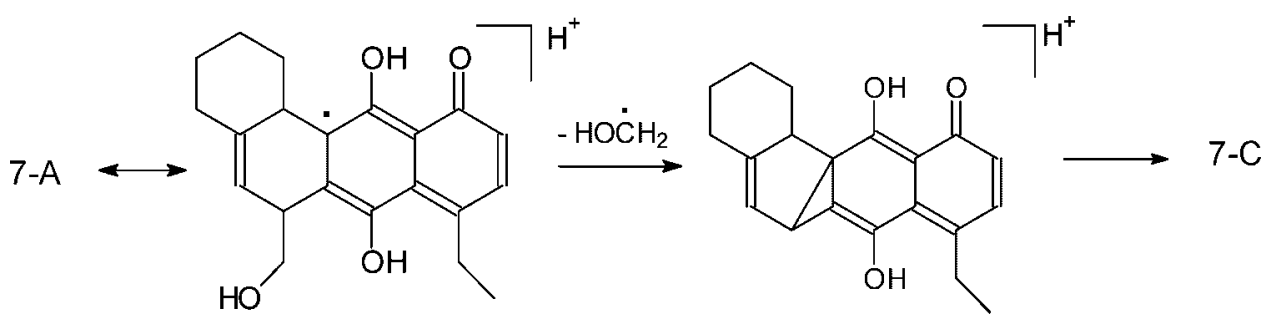

Scheme 12. Formation mechanism of 7-C from radical cation 7-A.<smiles>C=C1C=C2CCCCC2c2c(O)c3c(c(O)c21)C(C)(C)C=CC3=O</smiles><smiles>CCOc1ccccc1</smiles>

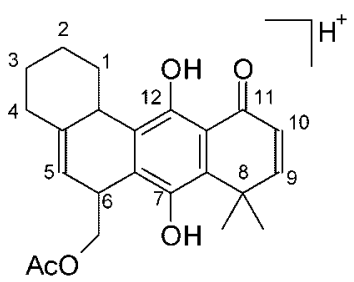

$8(383)$

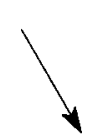



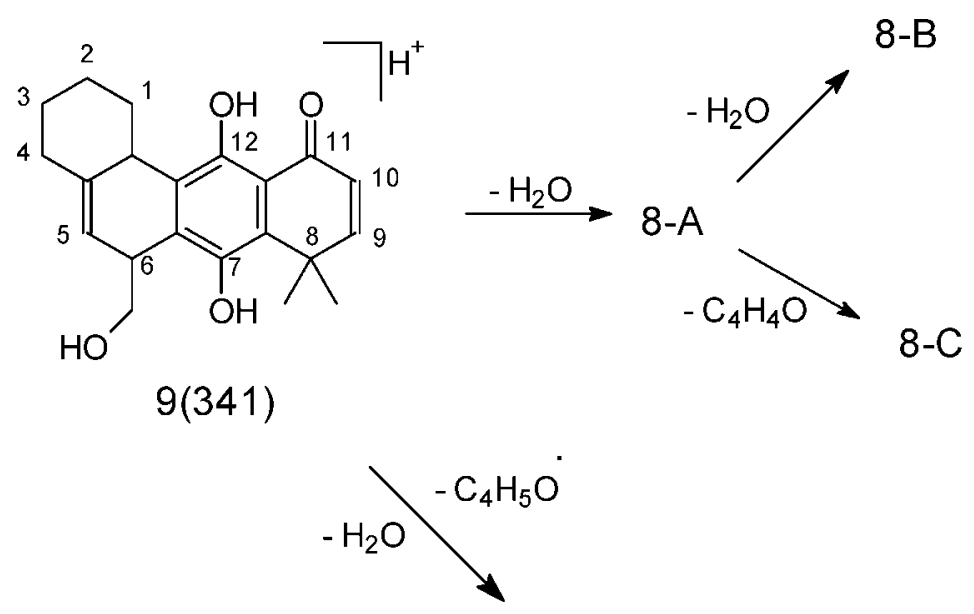<smiles>C=Cc1cc(O)c2c3c(cc(C)c2c1O)CCCC3</smiles>

9-A (254) or<smiles>C=Cc1cc(O)c2c(C)cc3c(c2c1O)CCCC3</smiles>

9-B (254)

Scheme 14. Fragmentation pattern of protonated hydroquinone 9.<smiles>[X]CC1C=C2CCCCC2c2c(O)c3c(c(O)c21)C(C)(C)C=CC(=O)C3=C</smiles>

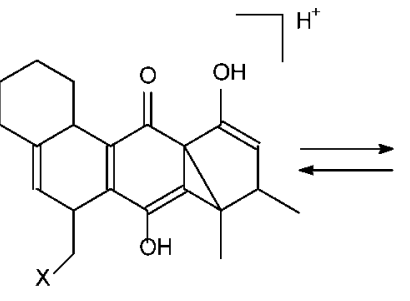<smiles>[Y]CC1C=C2CCCCC2C2=C1C(O)=C1C(=O)C3=C(O)C(O)=CC(C)[C@]31C2</smiles>

$-H X$

$-\mathrm{Me}-\dot{\mathrm{C}} \mathrm{H}-\mathrm{CH}=\mathrm{C}=\mathrm{O} \mid-\mathrm{HX}$

8-A<smiles>[3H]CCC12C(=C)C=C3CCCCC3c3c(O)c1c(C)c2c3O</smiles>

$9 A+9 B$
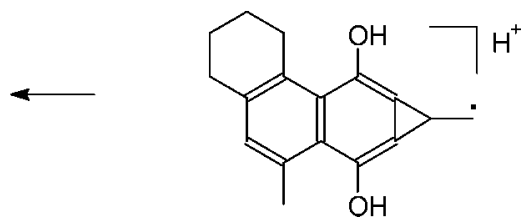

Scheme 15. Competing fragmentation pathways for compounds $8(X=O A c)$ and $9(X=O H)$. 
with the expulsion of the rather stable ketene radical $\mathrm{C}_{4} \mathrm{H}_{5} \mathrm{O}$. The resulting ion fragment rearranges to the cyclopropylmethyl radical, which undergoes a fast rearrangement, ${ }^{[23]}$ to give the aryl radical-cations 9-A or 9-B.

In conclusion, the analysis of the mass spectra of hydroquinones 1-9 revealed a subtle interplay of competing mechanisms in their fragmentation. These mechanisms included a sterically accelerated homolytic cleavage of an ethyl radical, in the case of compounds 3, 4 and 7; a Meerwein-type rearrangement with the loss of a ketene derivative, in the case of hydroquinones 6, 8, and 9; and competing mechanisms for dehydration, either through an intramolecular nucleophilic substitution, in the case of hydroquinones 4 and 5, or through an elimination of $\mathrm{OH}$ group from a primary alcohol, in the case of compounds 6, 7, and 9. Thus, the variety of fragmentation patterns observed for analogous compounds could be explained with the aid of these few mechanistic pathways.

\section{Acknowledgements}

We are grateful to CONICYT PBCT-PDA23, MECESUP UCH-116 and FONDECYT 1071077 grants for supporting this work. O. Ramírez-Rodríguez is grateful for MECESUP and DAAD PhD scholarships.

\section{REFERENCES}

[1] M. O. F. Goulart, C. L. Zani, J. Tonholo, L. R. Freitas, F. C. de Abreu, A. B. Oliveira, D. S. Raslan, S. Starling, E. Chiari. Bioorg. Med. Chem. Lett. 1997, 7, 2043.

[2] R. H. Thomson, Naturally Occurring Quinones, Academic Press, London, 1971, p. 2003.

[3] T. J. Monks, R. P. Hanzlik, G. M. Cohen, D. Ross, D. G. Graham. Toxicol. Appl. Pharmacol. 1992, 112, 2.

[4] F. C. Abreu, P. A. Ferraz, M. O. F. Goulart. J. Brazilian Chem. Soc. 2002, 13, 19

[5] L. Rodney, I. I. Nyland, M. Luo, M. R. Kelley, R. F. Borch. J. Med. Chem. 2010, 53, 1200.

[6] M. Pickhardt, Z. Gazova, M. von Bergen, I. Khlistunova, Y. Wang, A. Hascher, E. M. Mandelkow, J. Biernat, E. Mandelkow. J. Biol. Chem. 2005, 280, 3628.
[7] (a) J. N. Chen, Y. W. Huang, G. S. Liu, Z. Afrasiabi, E. Sinn, S Padhye, Y. Ma. Toxicol. Appl. Pharmacol. 2004, 197, 40; (b) Q. Huang, G. Lu, H. M. Sben, M. C. M. Cbung, C. N. Ong. Med. Res. Rev. 2007, 27, 609; (c) P. R. Dandawate, A. C. Vyas, S. B. Padhye, M. W. Singh, J. B. Baruah. Mini-Reviews Med. Chem. 2010, 10, 436.

[8] R. Araya-Maturana, T. Delgado-Castro, M. Gárate, J. Ferreira, M. Pavani, H. Pessoa-Mahana, B. K. Cassels. Bioorg. Med. Chem. 2002, 10, 3057.

[9] L. Mendoza, R. Araya-Maturana, W. Cardona, T. DelgadoCastro, C. García, C. Lagos, M. Cotoras. J. Agric. Food Chem. 2005, 53, 10080.

[10] R. Araya-Maturana, W. Cardona, B. K. Cassels, T. Delgado-Castro, J. Ferreira, D. Miranda, M. Pavani, H. PessoaMahana, J. Soto-Delgado, B. Weiss-López. Bioorg. Med. Chem. 2006, 14, 4664.

[11] J. Rodríguez, C. Olea-Azar, C. Cavieres, E. Norambuena, T. Delgado-Castro, J. Soto-Delgado, R. Araya-Maturana. Bioorg. Med. Chem. 2007, 15, 7058.

[12] M. Yadav, D. Patel, P. Singhal, R. Prasad, S. Goswani, P. S. Shrivastav, U. C. Pande. Rapid Commun. Mass Spectrom. 2008, 22, 511.

[13] A. E. M. Crotti, R. Vessecchi, J. L. C. Lopes, N. P. Lopes. Química Nova 2006, 29, 287.

[14] J. Zhao, T. Shoeib, K. W. M. Siu, A. C. Hopkinson. Int. J. Mass Spectrom. 2006, 255, 265.

[15] M. C. Thomas, T. W. Mitchell, S. J. Blanksby. J. Am. Soc. Mass Spectrom. 2005, 16, 926.

[16] V. E. Vandell, P. A. Limbach. J. Mass Spectrom. 1998, 33, 212.

[17] R. Vessecchi, A. E. M. Crotti, T. Guaratini, P. Colepicolo, S. E. Galembeck, N. P. Lopes. Mini-Reviews Org. Chem. 2007, 4, 75.

[18] K. Levsen, H. Schwarz. Mass Spectrom. Rev. 1983, 2, 77.

[19] F. J. Todd, F. W. McLafferty, Tandem Mass Spectrometry, John Wiley, New York, 1983, p. 149.

[20] W. Weinmann, M. Gergov, M. Goerner. Analysis 2000, 28, 934.

[21] C. G. Castro, J. G. Santos, J. C. Valcárcel, J. A. Valderrama. J. Org. Chem. 1983, 48, 3026.

[22] (a) H.-F. Wu, L.-W. Chen, C.-H. Chen. Rapid Commun. Mass Spectrom. 2001, 15, 1977; (b) A. W. Jones, M. A. Mikhailov, J. Iniesta, H. J. Cooper. J. Am. Soc. Mass Spectrom. 2010, 21, 268; (c) S. A. Pshenichnyuk, N. L. Asfandiarov, V. S. Fal'ko, V. G. Lukin. Int. J. Mass Spectrom. 2003, 227, 281; (d) F. W. McLafferty, F. Turecek, Interpretation of Mass Spectra, University Science Books, Mill Valley, USA, 1993, pp. 244-245.

[23] D. Griller, K. U. Ingold. Acc. Chem. Res. 1980, 13, 317. 